\title{
Rancang Bangun Aplikasi Pendeteksi Titik Koordinat Frekuensi Lightning Whistler
}

\author{
Philipus Novenando M Weking ${ }^{\mathrm{a} 1}$, I Putu Agung Bayupati ${ }^{\mathrm{a} 2}$, I Nyoman Piarsa ${ }^{\mathrm{a} 3}$ \\ aProgram Studi Teknologi Informasi Universitas Udayana \\ Bukit Jimbaran, Bali, Indonesia, telp. (0361) 701806 \\ 1'wekingevan17@gmail.com \\ bayuhelix@yahoo.com \\ 3manpits@unud.ac.id
}

\begin{abstract}
Abstrak
Bumi memiliki fenomena yang dapat dilihat secara langsung oleh makhluk hidup namun terdapat juga perubahan aktivitas bumi pada suatu waktu tertentu yang tidak biasa dilihat oleh manusia. Fenomena tersebut terdapat pada lapisan udara bumi atau atmosfer dimana salah satunya adalah Lightning Whistler. Lightning Whistler merupakan bentuk gelombang elektromagnetik yang terdengar dalam bentuk suara seperti siulan sesaat setelah kilat berlangsung pada lapisan magnetosfer dan ionosfer. Gelombang siulan yang merambat pada frekuensi radio disebut whistler wave. Aplikasi Pendeteksi Titik Koordinat Frekuensi Lightning Whistler yang dikembangkan pada penelitian ini bertujuan untuk mendeteksi dan memperoleh titik koordinat whistler wave. Deteksi Lightning Whistler dilakukan melalui penerapan metode Short Time Fourier Transform (STFT), image processing, dan morphology image. Metode STFT bertujuan untuk melakukan konversi data audio menjadi citra spektogram. Image processing diterapkan pada citra spektogram untuk menghilangkan noise. Proses morphology image diterapkan pada hasil image processing bertujuan untuk mempertebal sinyal gelombang whistler sehingga mempermudah melakukan pendeteksian titik koordinat yang dilakukan pada proses akhir. Aplikasi ini mampu mendeteksi titik koordinat dari sinyal whistler wave berupa informasi lokasi titik koordinat sinyal yang dimunculkan dan jumlah sinyal yang terdeteksi berdasarkan periode dan waktu.
\end{abstract}

Kata kunci: Lightning Whistler, Whistler Wave, STFT, Image Processing.

\begin{abstract}
Unusual activities of earth can be seen by human on a certain time caused by some earth activities change. One of them is the phenomena on atmosphere namely Lightning Whistler. Lightning Whistler is an electromagnetic wave that happens after a lighting on the magnetosphere and ionosphere, where a sound like a whistle is produced. This wave that traverse on radio frequency is called as whistler wave. This research proposed an application for detecting the frequency coordinate of a lightning whistler. The proposed application used STFT, image processing, and morphology image. STFT method is used to convert audio data into spectrogram image data. Afterwards, spectrogram image is processed by using image processing method to reduce noise. Finally, morphology image method is implemented to thicken the whistler wave signal to simplify the detection of coordinate. The proposed application can detect coordinate of a whistler wave signal, in the form of coordinate location, and the number of detected signal, based on time and period.
\end{abstract}

Keywords: Lightning Whistler, Whistler Wave, STFT, Image Processing

\section{Pendahuluan}

Bumi memiliki lapisan yang berguna dalam kehidupan manusia yang sering disebut dengan lapisan atmosfer. Beberapa aktivitas bumi terjadi di dalam atmosfer. Aktivitas bumi dapat mengalami perubahan sehingga muncul aktivitas baru yang tidak biasa dilihat maupun didengar manusia. Aktivitas ini disebut fenomena, Salah satu fenomena yang muncul dalam lapisan atmosfer adalah fenomena whistler. Whistler adalah sebuah metode perambatan yang berasal 
dari suara kilat atau lightning untuk gelombang frekuensi rendah dengan jarak 3-30 kHz. Gelombang whistler merambat dari pemisahan gelombang kilat jauh ke dalam Magnetosfer dan menyatukan energi dari atmosfer ke Magnetosfer melalui media terionisasi yang tertanam di bidang geomagnetik sehingga menyebar dan dapat membentuk gelombang whistler dalam bentuk spektogram (spektrum dinamis dalam frequency time domain) yang dapat diperoleh. Whistler wave merambat sepanjang garis medan magnet dipolar yang berinteraksi dengan elektron energik dan memencarkan gelombang dari sabuk radiasi Van Allen ke atmosfer. Elektron energik menghasilkan ionisasi tambahan pada $D$-region dan memodifikasi listrik konduktivitas atmosfer [1].

Komposisi dari gelombang lightning whistler terdiri dari Geomagnetic Storms yang muncul akibat gangguan geomagnetik dimana magnetic field dari bumi bertabrakan dengan magnetic field lain yang ada pada lapisan bumi, contohnya solar flare. Komposisi yang kedua adalah whistler atau bunyi siulan yang dihasilkan pada lapisan Magnetosfer. Komposisi yang ketiga adalah Geomagnetic Signals adalah sebuah kumpulan energi yang masuk akibat efek geomagnetik bumi ke dalam lapisan magnetosfer dan menghasilkan sinyal yang dapat ditangkap oleh radio berdasarkan tingkat radiusnya [2].

Data dari gelombang lightning whistler diteliti untuk mendapatkan data yang diperlukan berupa informasi mengingat penelitian terhadap whistler sedikit jumlahnya, maka diperlukan sebuah aplikasi yang dapat menampilkan informasi mengenai whistler, salah satunya adalah menampilkan informasi titik koordinat dari data whistler. Aplikasi yang dirancang mampu menghitung titik koordinat awal dan akhir dari data sinyal suara whistler berdasarkan periode dan waktu. Perancangan aplikasi menggunakan metode STFT sebagai media konversi data whistler. Image Processing digunakan untuk melakukan proses pengolahan citra spectogram. Morphology Image digunakan untuk mendapatkan data sinyal whistler menjadi lebih jelas sehingga mempermudah pendeteksian titik koordinat.

\section{Metodologi Penelitian}

Tahap-tahap yang dilakukan untuk mendapatkan output dari aplikasi ini adalah sebagai berikut :

a. Tahap Pengumpulan Data

Tahap Pengumpulan Data membahas jenis data yang digunakan dalam aplikasi. Data yang digunakan untuk menjalankan aplikasi adalah data audio whistler dalam format .wav. Data whistler tersebut dapat diunduh di internet.

b. Tahap Perancangan Gambaran Umum Sistem dan Flowchart Aplikasi

Tahap Perancangan Gambaran Umum Sistem dan Flowchart Aplikasi menjelaskan bagaimana bentuk Gambaran Umum Sistem beserta alur flowchart yang digunakan dalam aplikasi. Bentuk gambaran umum sistem yang digunakan aplikasi seperti pada Gambar 1.

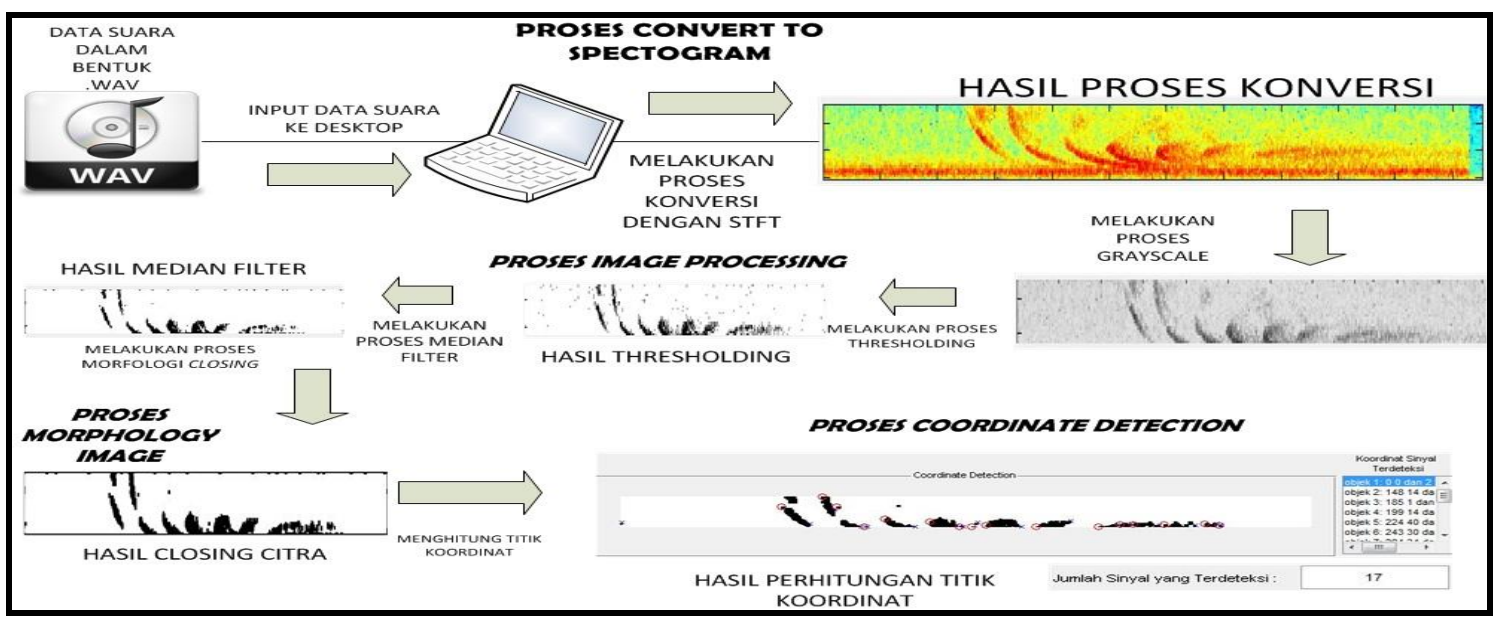

Gambar 1. Gambaran Umum Sistem 
Gambaran umum sistem pada Gambar 1 menjelaskan bahwa proses aplikasi dimulai dengan melakukan input data audio ke dalam aplikasi. Data audio tersebut kemudian dikonversi dengan menggunakan metode STFT hingga hasilnya keluar pada aplikasi. Proses image processing dilakukan pada citra hasil konversi, dimulai dari proses grayscale, thresholding, dan median filter. Proses selanjutnya adalah melakukan proses morphology image dengan metode closing. Perhitungan titik koordinatnya kemudian dilakukan setelah citra hasil proses morphology image diperoleh. Alur bagaimana jalannya aplikasi dituangkan dalam bentuk flowchart atau alur data aplikasi.

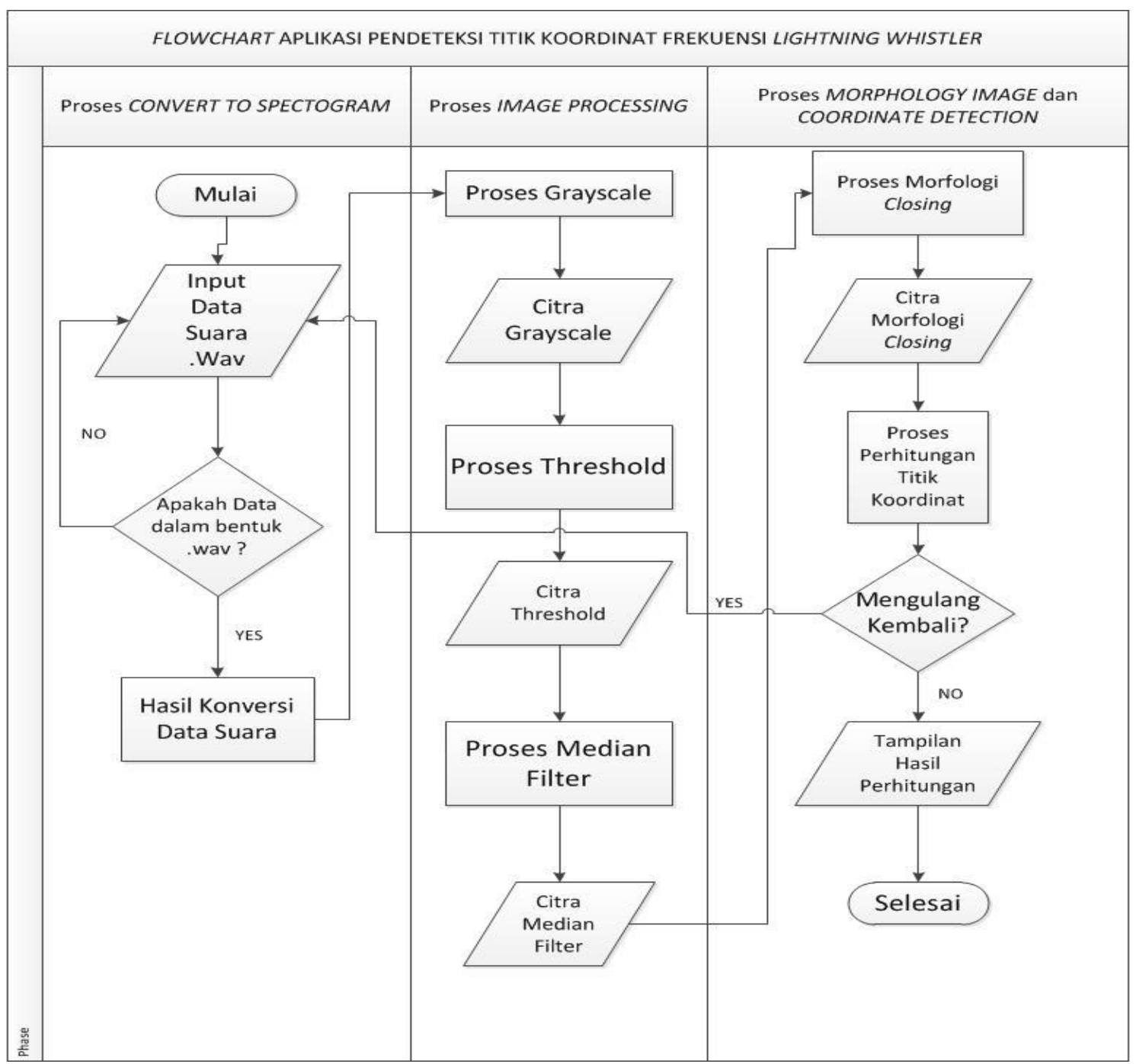

Gambar 2. Flowchart Aplikasi

Flowchart pada Gambar 2 menunjukkan alur proses aplikasi secara spesifik bagaimana aplikasi dapat berjalan. Alur dimulai dengan melakukan input data audio whistler kemudian dilakukan pengecekan apakah data yang dimasukkan dalam format .wav, jika salah maka harus memulai input ulang data dan jika benar maka dilanjutkan dengan melakukan konversi data sampai mendapatkan hasil. Alur dilanjutkan ke proses image processing dimana proses ini dilakukan secara berurutan dimulai dengan melakukan proses grayscale, thresholding, dan median filter. Hasil dari image processing dilanjutkan ke proses morphology image menggunakan metode closing dengan hasil citra yang lebih mudah dideteksi sinyalnya. Alur berlanjut ke proses deteksi perhitungan titik koordinat untuk mendapatkan hasil lokasi titik koordinat. 
c. Perancangan Interface Aplikasi

Tahap ini menjelaskan pembuatan rancangan interface pada aplikasi. Interface pada aplikasi ditampilkan pada Gambar 3.

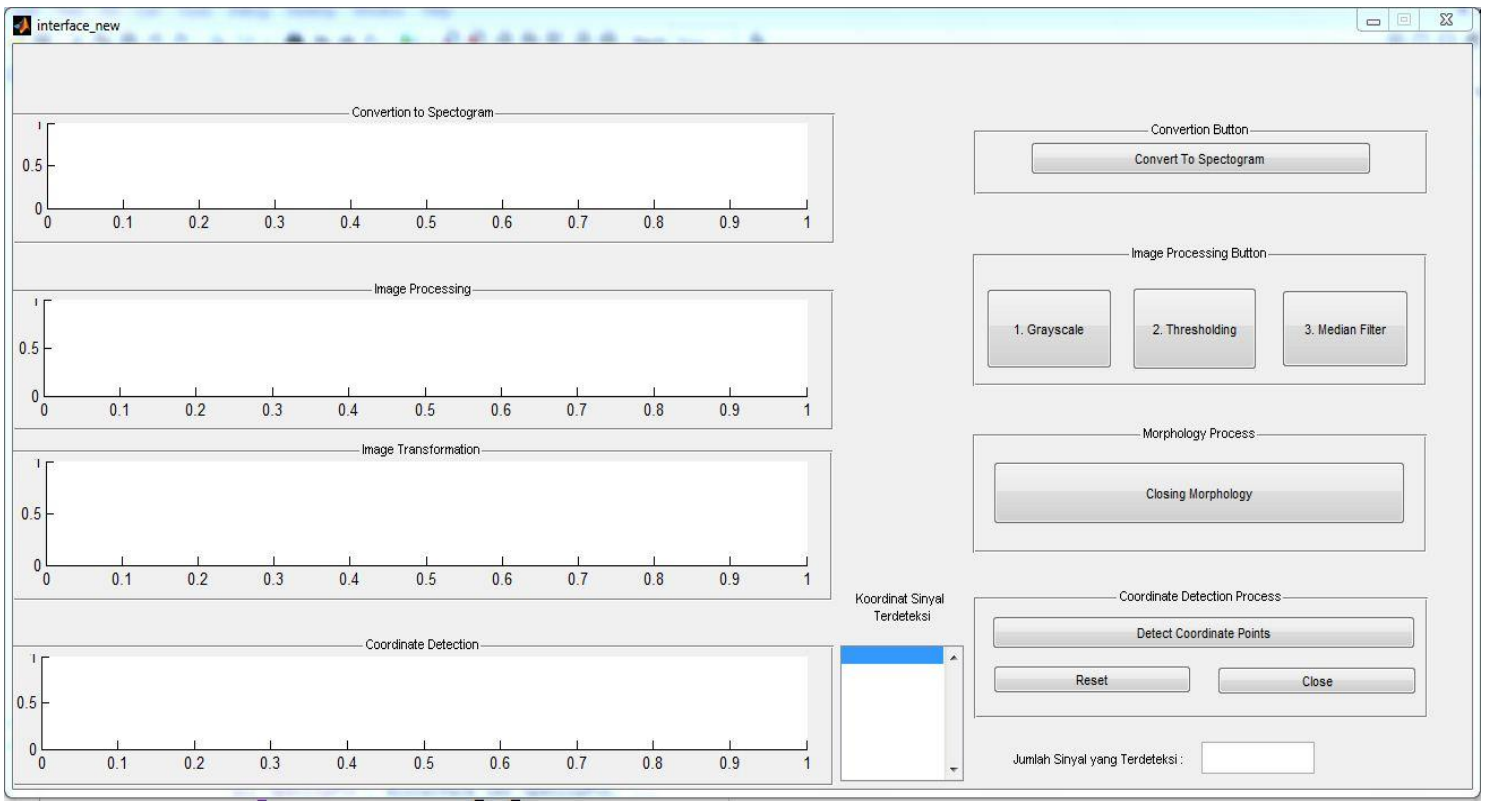

Gambar 3. Tampilan Interface Aplikasi

Tampilan interface pada Gambar 3 merupakan tampilan yang memiliki 4 proses utama dimana proses utama tersebut meliputi proses Convertion, Image Processing, Morphology Process, dan Coordinate Detection Process. Proses Convertion merupakan proses konversi data audio menjadi bentuk citra spectogram. Proses Image Processing Button merupakan proses pada data citra spectogram dengan output hasil adalah dalam bentuk citra biner. Proses Morphology Process adalah untuk mendapatkan citra hasil dengan penebalan sinyal yang lebih detail. Proses Coordinate Detection Points adalah proses yang bertujuan melakukan hitungan titik koordinat sehingga menampilkan informasi mengenai sinyal yang dideteksi.

\section{Kajian Pustaka}

\subsection{State of the Art}

State of the Art menjelaskan penelitian sebelumnya dan membandingkan dengan penelitian yang dilakukan saat ini. Penelitian yang dilakukan oleh V.S. Sonwalkar dengan judul WhistlerMode Wave-Injection Experiments In The Plasmasphere With A Radio Sounder menyatakan bahwa dalam melakukan proses injeksi gelombang whistler, komposisi dari gelombang frekuensi lightning whistler dapat diolah dari tipe VLF (very low frequency). VLF (very low frequency) adalah tipe gelombang yang memiliki frekuensi antara $3 \mathrm{~Hz}-30 \mathrm{~Hz}$ sehingga lightning whistler dikategorikan dalam tipe VLF. Tipe VLF digunakan untuk mencari gelombang injeksi dari lightning whistler melalui lapisan plasmasphere dalam penelitian injeksi lightning whistler menggunakan pengeras suara radio. Penelitian tersebut menggunakan antena radio sebagai sarana untuk penyaluran gelombang lightning whistler dalam lapisan Plasmasphere. Hasil dari penelitian mampu melakukan input suara whistler melalui antena radio dengan metode injeksi sehingga mendapatkan data whistler berupa suara [3].

Setya Darma dalam penelitiannya yang berjudul Automatic Lightning Whistler Detection Using Connected Component Labeling Method menjelaskan bahwa data Lightning Whistler memiliki beberapa jenis gelombang sinyal yang terdeteksi berdasarkan periode waktu tertentu. Gelombang sinyal kemudian diproses dengan melakukan deteksi jumlah sinyal whistler beserta pola gelombang whistler menggunakan citra dengan metode image processing, Penelitian ini 
telah berhasil melakukan perhitungan deteksi gelombang whistler menggunakan data citra spectrogram [4] .

Penelitian yang telah dilakukan oleh V.S. Sonwalkar terbatas pada penggunaan data whistler ke radio melalui proses injeksi, data yang dihasilkan hanya data suara saja, sedangkan Setya Darma pada penelitiannya terbatas pada menghitung jumlah sinyal whistler yang terdeteksi dari citra spectogram yang sudah ada.

\subsection{Whistler Wave}

Whistler wave adalah gelombang elektromagnetik yang merambat melalui atmosfer terkadang terdeteksi oleh audio sensitif amplifier sebagai pengukuran tinggi rendahnya suara. Proses dari gelombang siulan terakhir berkisar rentang waktu setengah detik, dan mereka dapat diulang secara berkala beberapa detik, semakin panjang dan lebih redup dengan waktu.

Gelombang elektromagnetik whistler muncul setiap kali petir menyambar dan biasanya dalam rentang frekuensi antara 300 sampai $30.000 \mathrm{~Hz}$. Whistler Wave merambat melalui lapisan ionosfer yaitu bagian dari atmosfer dimana pada lapisan ionosfer jumlah ion cukup besar untuk mempengaruhi propagasi gelombang radio yang dimulai pada ketinggian sekitar 50 $\mathrm{km}$ (30 mil) di atas permukaan bumi [5].

\subsection{Short Time Fourier Transform (STFT)}

Short Time Fourier Transform (STFT) adalah metode proses sinyal yang digunakan untuk menganalisis sinyal yang bersifat non-stationery. Karakteristik dari statistik STFT berhubungan dengan waktu yang digunakan. Sifat STFT yaitu STFT mengekstraksi beberapa frame sinyal untuk di analisa menggunakan waktu. Ekstraksi dari Metode STFT digunakan untuk membantu proses kerja dari FFT sehingga mendapatkan jarak waktu yang diperlukan.

STFT merupakan perhitungan yang bersumber dari DFT (Discrete Fourier Transform) dengan mengambil nilai DFT ke dalam subset data berkelanjutan sehingga membentuk jarak waktu baru yang disebut window. STFT dapat dihitung dengan cara menghitung jarak nilai DFT, memindahkan window dengan menggunakan cara one time index dan menghitung kembali nilai DFT. Proses tersebut menghasilkan sebuah jarak waktu baru. STFT dapat dilihat pada Persamaan 1.

$$
A_{k}^{t}=\frac{1}{\sqrt{N}} \sum_{j-0}^{N-1} X_{j+t-N+1 \omega N}-j k
$$

Persamaan 1 dilakukan untuk menghitung jarak waktu yang diperlukan sesuai dengan durasi data audio whistler yang dimasukkan untuk mendapatkan jarak waktu yang baru. Periode (k) dan waktu (t) memiliki nilai tertentu seperti Persamaan 2.

$$
k=0,1, \ldots, N-1 t=N-1, \ldots, M-1
$$

Persamaan 2 menghitung nilai dari periode dan waktu sehingga menghasilkan nilai baru untuk periode dan waktu yang bertujuan untuk proses konversi data audio [6].

\subsection{Image Processing}

Pengolahan citra atau image processing adalah bidang yang berhubungan dengan proses transformasi citra atau gambar yang bertujuan untuk mendapatkan kualitas yang baik ataupun mendapatkan hasil pengolahan yang sesuai dengan yang diinginkan, sedangkan pengenalan pola atau pattern recognition adalah bidang yang berhubungan dengan proses identifikasi objek pada citra atau gambar yang bertujuan untuk memperoleh informasi atau data dari citra. Image Processing memiliki beberapa metode tahapan yang digunakan antara lain :

a. Grayscale

Grayscale merupakan teknik pemetaan intensitas dimana tiap panel diberikan nilai keabuan yang baru untuk meningkatkan ketajaman gambar. Operasi grayscale tidak merubah bentuk dan geometri image, yang berubah hanya level intensitasnya. Teknik dari proses grayscale dilakukan dengan cara memproses histogram tingkat keabuan (gray level histogram) dari image. 


\section{b. Thresholding}

Thresholding adalah metode untuk mengubah grayscale image menjadi binary image sehingga objek yang diinginkan terpisah dari latar belakangnya. Thresholding merupakan metode paling sederhana, dimana tiap objek atau region image dibedakan berdasarkan penyerapan cahaya atau reflektifitas konstan pada permukaannya. Suatu nilai threshold (nilai konstan brightness) dapat ditentukan untuk membedakan objek dengan latar belakangnya. Tujuan dari thresholding adalah untuk memisahkan pixel yang mempunyai nilai keabuan (gray value) lebih tinggi dengan yang lebih rendah. Misalnya pixel yang nilai keabuannya lebih tinggi diberi nilai biner 1 sedangkan pixel dengan nilai keabuan lebih rendah diberi nilai biner 0 . Berdasarkan penentuan nilai threshold yang digunakan, metode thresholding dapat dibedakan menjadi metode manual dimana nilai threshold adalah tetap dan ditentukan secara manual, dan metode otomatis, dimana nilai threshold ditentukan oleh sistem secara otomatis berdasarkan pengetahuan sistem akan objek, lingkungan dan aplikasinya (misalnya karakteristik intensitas objek, ukuran objek, daerah image yang diduduki objek, jumlah jenis objek dalam image). Thresholding otomatis menganalisis penyebaran nilai keabuan dalam image dengan menggunakan histogram dan pengetahuan akan aplikasi tersebut untuk menemukan threshold paling cocok.

\section{c. Filtering}

Filtering merupakan suatu metode yang tergabung dalam group operation pada pixel, menghitung nilai pixel baru dengan menggunakan pixel-pixel tetangganya. Filtering dijelaskan dengan istilah template convolution dimana template-nya adalah suatu matriks koefisien bobot yang umumnya ganjil dan sama sisi, misalnya $3 \times 3,5 \times 5$. Nilai pixe/ baru dihitung dengan menempatkan template pada suatu titik, kemudian nilai-nilai pixel dikalikan dengan bobot dan ditambahkan sebagai nilai keseluruhan, jumlah tersebut menjadi nilai baru bagi pixe/ di tengah template. Hasil jumlah tersebut yang menjadi pixel bagi image baru. Proses filtering diulang pada semua pixel dalam gambar. Operator yang sering digunakan adalah averaging, gaussian, dan median filtering [7][8].

\subsection{Morphology Image Closing}

Morphological Operation atau operasi morfologi adalah sebuah operasi dalam pengolahan citra untuk memperbaiki atau mengisi pixel untuk menutupi bagian pixel yang dianggap rusak atau kurang. Operasi morfologi citra memiliki beberapa jenis yang digunakan dalam pengolahan citra. Proses morfologi citra ada empat jenis yaitu morfologi dilasi, erosi, openiku, dan closing. Salah satu proses morfologi yang sering yang sering digunakan dalam pengolahan citra biner adalah morfologi metode closing.

Metode Closing adalah salah satu proses morfologi citra dimana operasi closing dilakukan pada citra biner. Metode closing merupakan gabungan dari proses morfologi dilasi dan erosi dimana proses closing dimulai dari proses dilasi kemudian dilanjutkan dengan proses erosi. Proses closing dilakukan dengan cara menutup beberapa pixel yang diperlukan untuk menyambungkan beberapa citra yang dianggap terpisah sehingga menjadikan dua citra menjadi satu [9].

\section{Hasil dan Pembahasan}

Aplikasi Pendeteksi Titik Koordinat Frekuensi Lightning Whistler memiliki beberapa tahap uji coba untuk mendapatkan hasil titik koordinat. Tahap uji coba meliputi uji coba aplikasi proses konversi audio ke spectrogram. Tahap yang kedua adalah uji coba aplikasi proses image processing. Tahap ketiga yang dilakukan yaitu uji coba aplikasi proses morphology image. Tahap keempat adalah uji coba aplikasi proses coordinate detection.

\subsection{Uji coba aplikasi proses konversi audio ke spectogram}

Proses uji coba Aplikasi Perhitungan Titik Koordinat Frekuensi Lightning Whistler dilakukan hingga menghasilkan keluaran berupa citra spectrogram yang telah terhitung titik koordinatnya melalui beberapa proses yang ada dalam aplikasi. Proses pertama yang dilakukan adalah proses konversi audio menjadi spectogram pada menu interface, seperti pada Gambar 4. 


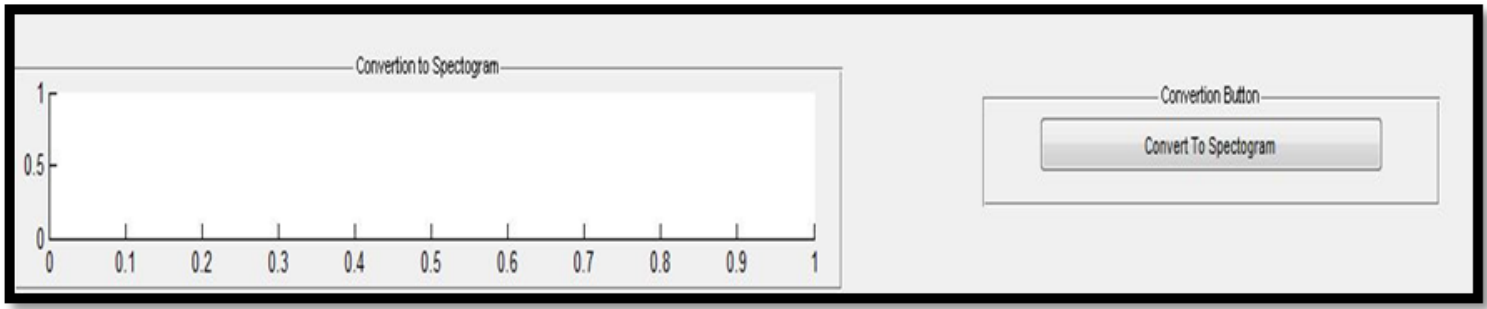

Gambar 4. Tampilan Proses Konversi Audio

Tampilan Proses Konversi Audio dilakukan dengan klik pada tombol Convert To Spectogram maka hasil proses dimunculkan seperti Gambar 5.

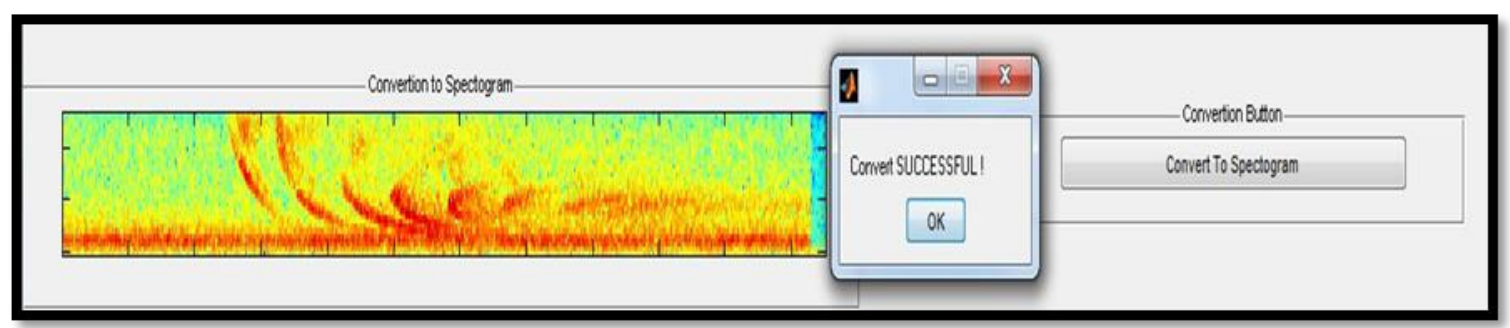

Gambar 5. Hasil Proses Konversi Audio

Hasil pada Gambar 5 menunjukkan bahwa data audio telah dikonversi menjadi bentuk spectogram dengan metode STFT dan spectogram tersebut sudah dikonversi langsung menjadi image. Hasil proses memunculkan pesan "Convert SUCCESSFUL" jika konversi tersebut berhasil dilakukan.

\subsection{Uji coba aplikasi proses image processing}

Uji coba untuk proses image processing dilakukan setelah proses konversi audio ke dalam bentuk spectogram telah selesai dilakukan dan hasilnya telah dimasukkan ke dalam aplikasi dalam format image. Proses image processing dapat dilihat pada bagian interface seperti Gambar 6.

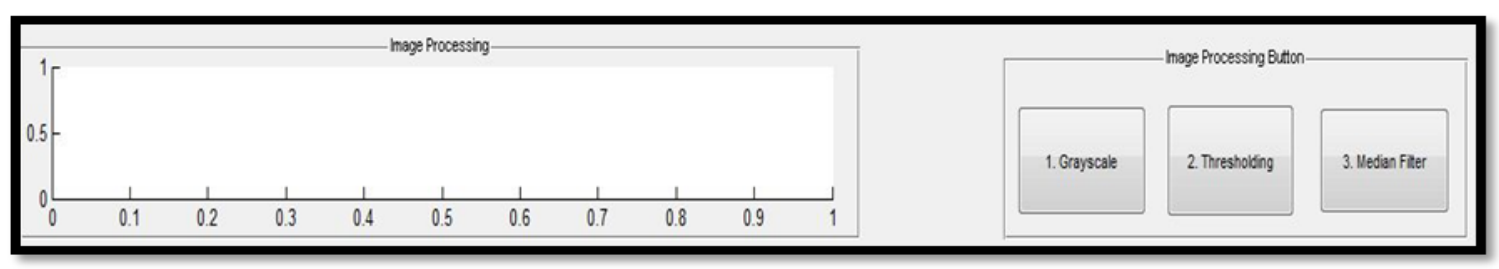

Gambar 6. Tampilan Proses Image Processing

Proses image processing dilakukan secara berurutan, dimulai dari Grayscale, Thresholding, hingga Median Filter. Hasil dari ketiga proses tersebut ditunjukkan pada Gambar 7, Gambar 8, dan Gambar 9.

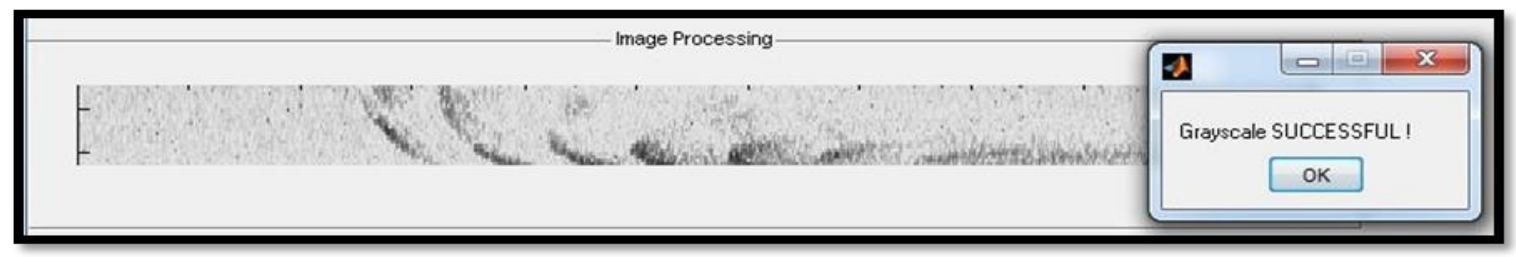

Gambar 7. Hasil Proses Grayscale 
Hasil proses Grayscale menunjukkan bahwa nilai pixel dari citra spektogram telah berubah dari nilai RGB menjadi nilai keabuan. Proses dilanjutkan dengan melakukan thresholding pada citra grayscale sehingga mendapatkan hasil seperti Gambar 8.

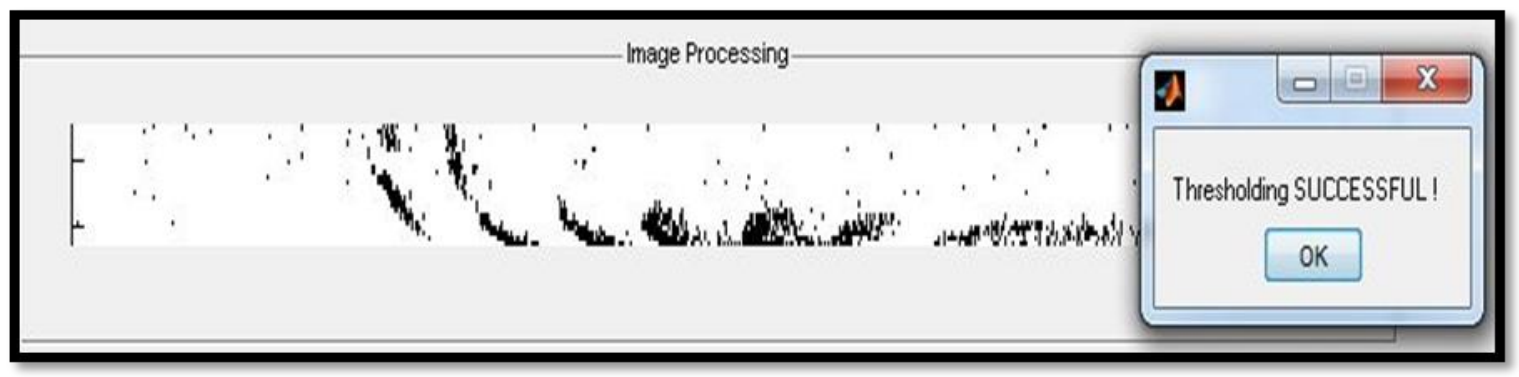

Gambar 8. Hasil Proses Thresholding

Hasil Thresholding menunjukkan bahwa sebagian besar noise yang ada pada citra telah berhasil dihilangkan. Citra pada Gambar 8 juga telah diubah menjadi citra biner. Proses thresholding dilanjutkan dengan median filter seperti Gambar 9.

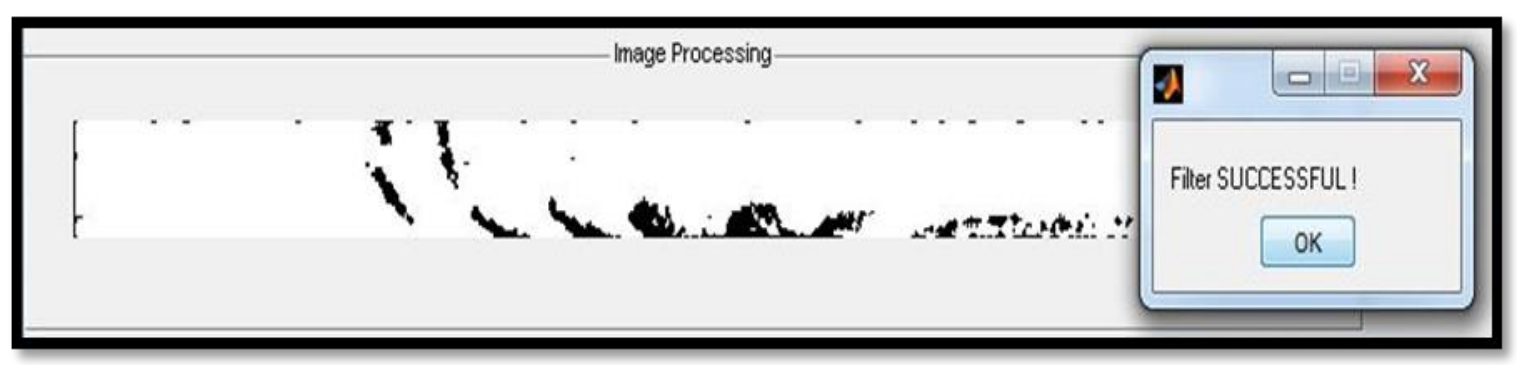

Gambar 9. Hasil Proses Median Filter

Hasil proses median filter menghilangkan sisa noise dari citra yang belum dihilangkan dari proses thresholding. Hasil dari proses tersebut berupa citra biner.

\subsection{Uji coba aplikasi proses morphology image}

Uji coba untuk proses image morphology dilakukan setelah proses image processing, dan hasil akhir dari proses image processing berbentuk citra biner. Proses morphology image hanya meliputi proses Closing pada citra, yang dilakukan pada bagian interface ditunjukkan seperti pada Gambar 10.

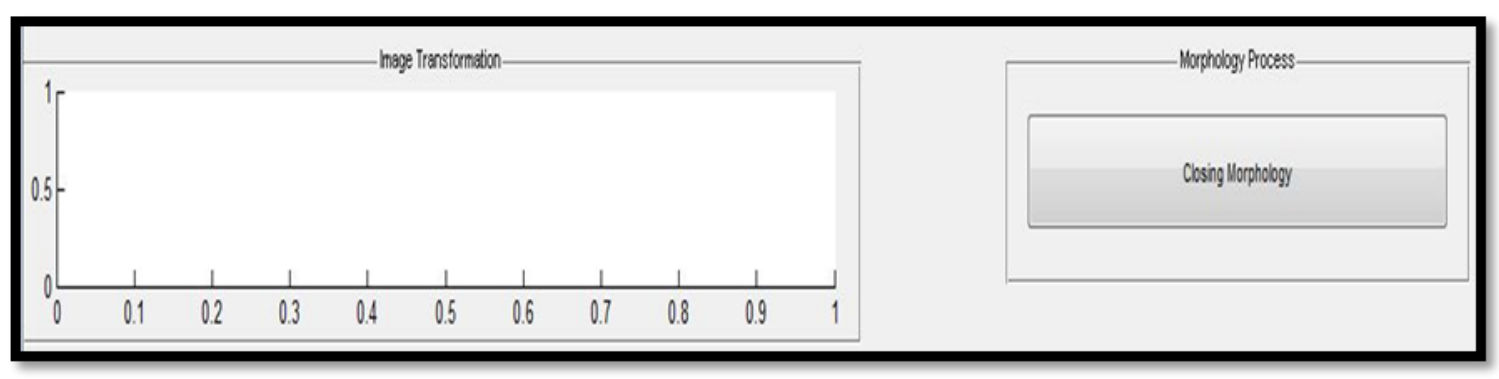

Gambar 10. Tampilan Proses Morphology

Proses Morphology Image bertujuan untuk mendapatkan sinyal yang ada pada citra biner untuk melakukan proses deteksi titik koordinat pada proses akhir. Hasil yang didapatkan dalam proses morphology image ini ditampilkan pada Gambar 11. 


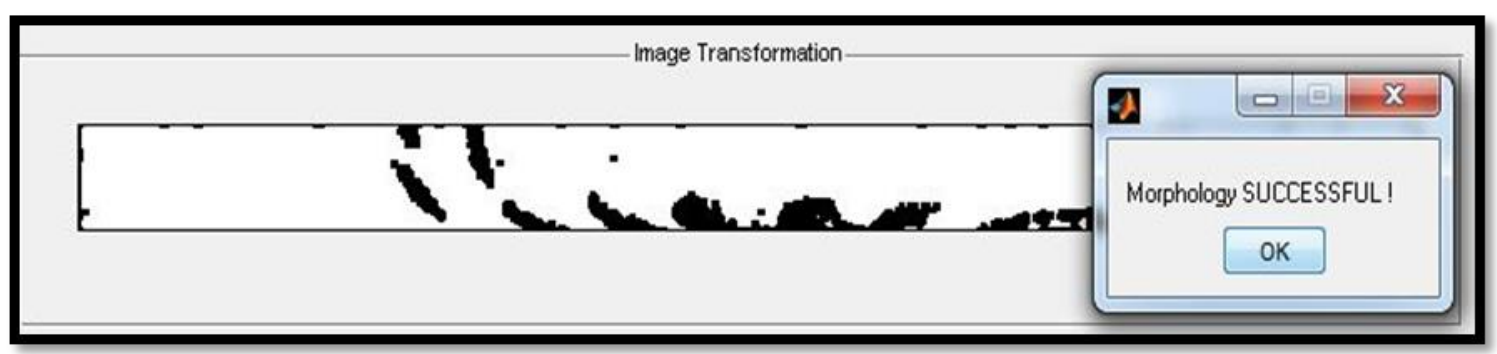

Gambar 11. Hasil Proses Morphology

Hasil proses Morphology menunjukkan bahwa citra sinyal menjadi semakin tebal dan detail untuk mempermudah proses pendeteksian.

\subsection{Uji coba aplikasi proses coordinate detection}

Uji coba untuk proses coordinate detection dilakukan setelah proses Morhology Image. Proses Coordinate Detection merupakan proses akhir dari Aplikasi Pendeteksi Titik Koordinat Frekuensi Lightning Whistler. Proses hanya meliputi satu bagian proses yaitu Detect Coordinate Points. Proses dilakukan pada bagian interface seperti Gambar 12.

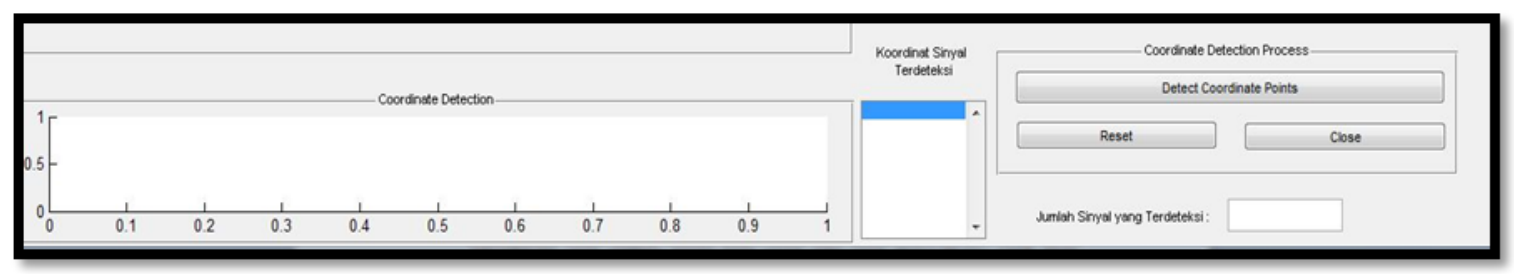

Gambar 12. Tampilan Proses Coordinate Detection

Proses Coordinate Detection bertujuan untuk mendapatkan informasi titik koordinat meliputi titik awal dan titik akhir koordinat dari semua sinyal yang ada dalam citra tersebut. Proses diawali dari citra hasil morfologi yang telah dilakukan. Hasil dari proses meliputi deteksi titik koordinat, jumlah sinyal yang terdeteksi, dan lokasi koordinat deteksi seperti pada Gambar 13 dan Gambar 14.

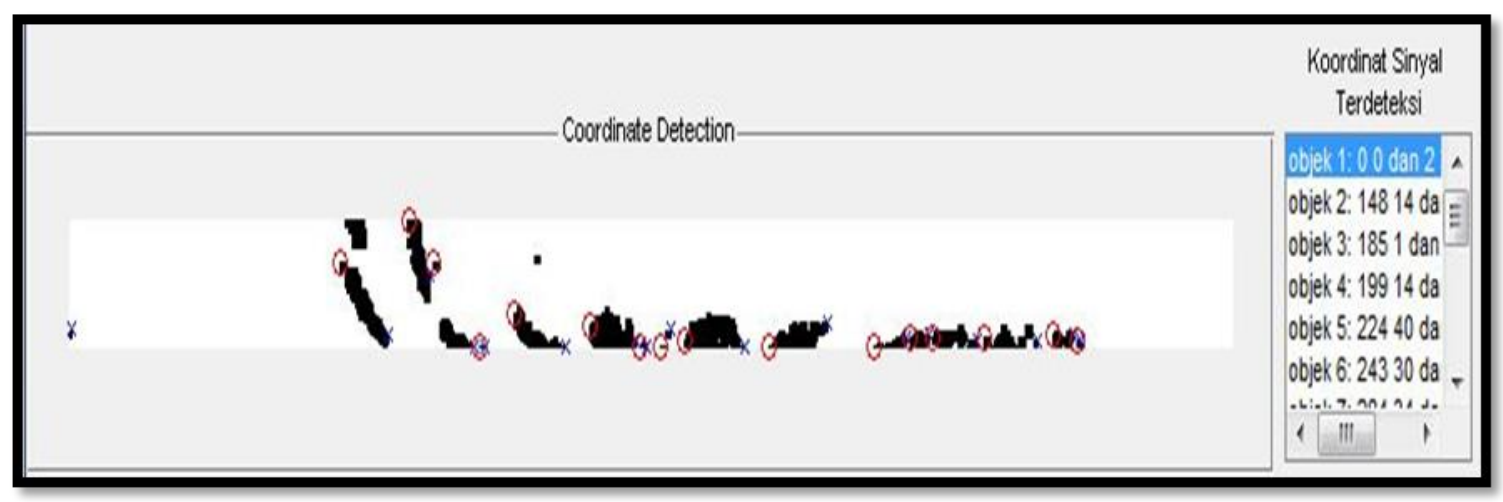

Gambar 13. Hasil Proses Coordinate Detection beserta lokasi koordinat

Proses pada Gambar 13 menunjukkan lokasi titik koordinat frekuensi dari tiap sinyal whistler yang terdeteksi dari citra spektogram tersebut. Proses deteksi juga menampilkan jumlah sinyal whistler yang terdeteksi seperti Gambar 14. 


\section{Jumlah Sinyal yang Terdeteksi :}

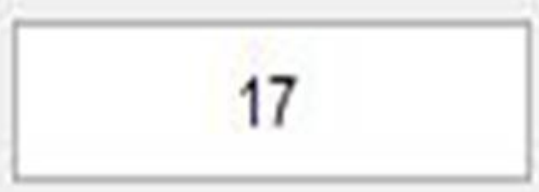

Gambar 14. Jumlah Sinyal Terdeteksi

\section{Kesimpulan}

Aplikasi Pendeteksi Titik Koordinat Frekuensi Lightning Whistler pada penelitian ini dapat menghasilkan informasi titik koordinat dari frekuensi sinyal whistler wave. Proses Aplikasi Pendeteksi Titik Koordinat Frekuensi Lightning Whistler dihasilkan melalui empat tahapan proses yaitu proses konversi ke spectogram, proses image processing, proses morphology image, dan proses coordinate detection. Proses konversi ke spectogram diterapkan untuk mendapatkan citra spectogram menggunakan metode STFT. Penerapan proses image processing ditujukan untuk mendapatkan citra biner melalui tahap secara berurutan dimulai dari grayscale untuk menghasilkan citra keabuan, thresholding untuk mendapatkan citra biner dan membersihkan noise, dan median filter untuk menghasilkan citra biner yang lebih bersih. Proses image morphology menampakkan hasil penebalan data sinyal pada citra biner. Proses coordinate detection diterapkan untuk menghasilkan data titik koordinat berupa lokasi koordinat dan jumlah sinyal terdeteksi berdasarkan periode dan waktu. Aplikasi Pendeteksi Titik Koordinat Frekuensi Lightning Whistler telah berhasil menampilkan informasi mengenai titik koordinat frekuensi dari data sinyal yang terdeteksi pada citra biner.

\section{Daftar Pustaka}

[1] D. Siingh et al., "Thunderstorms, lightning, sprites and magnetospheric whistler-mode radio waves," Surveys in Geophysics. 2008.

[2] J. Wallace, "Amateur Radio Astronomy Projects-A Whistler Radio," 111Birden St, Torrington, pp. 20-23, 2010.

[3] V. S. Sonwalkar, X. Chen, J. Harikumar, D. L. Carpenter, and T. F. Bell, "Whistler-mode wave-injection experiments in the plasmasphere with a radio sounder," Journal of Atmospheric and Solar-Terrestrial Physics, 2001.

[4] K. S. Dharma, I. P. A. Bayupati, and P. W. Buana, "Automatic lightning whistler detection using connected component labeling method," Journal of Theoretical and Applied Information Technology, 2014.

[5] R. A. Hart, C. T. Russell, and T. L. Zhang, "An Overview of Lightning Induced WhistlerMode Waves Observed By Venus Express," in 46th Lunar and Planetary Science Conference, 2015.

[6] S. Okamura, "The Short Time Fourier Transform and Local Signals," Carnegie Mellon University, 2011.

[7] A. Kulkarni, Computer Vision \& Fuzzy. New Jersey: Prentice Hall.Inc, 2011.

[8] R. Davies, Computer and Machine Vision, 4th Edition Theory, Algorithms, Practicalities Opsylum. 2012.

[9] A. M. Raid, W. M. Khedr, M. A. El-Dosuky, and M. Aoud, "Image Restoration Based on Morphological Operations," International Journal Computer Science Engineering Information Technology, 2014. 